\title{
How to Teach Phrasal Verbs
}

\author{
Cagri Tugrul Mart \\ Department of Languages, Ishik University, Erbil, Iraq \\ Tel: 964-750-308-6122Ｅ-mail: tugrulbey@hotmail.com
}

Received: February 13, 2012

Accepted: March 9, 2012

Published: June 1, 2012

doi:10.5539/elt.v5n6p114

URL: http://dx.doi.org/10.5539/elt.v5n6p114

\begin{abstract}
Teaching phrasal verbs is a difficult area. Many a study has proved that contextualization has an important positive effect on the ability of the students to decipher the correct meaning of a phrasal verb. In this article you will read some useful approaches to the presentation of phrasal verbs through context to improve the students' level of understanding. This article also suggests some other useful tips for teaching phrasal verbs.
\end{abstract}

Keywords: Phrasal verbs, Context, Song

\section{Introduction}

A Phrasal Verb is a phrase which consists of a verb in combination with a preposition or adverb or both, the meaning of which is different from the meaning of its separate parts: 'look after', 'work out' and 'make up for' are all phrasal verbs (Koprowski, 2005). According to Trask (1993: 208) a phrasal verb is lexical verb "which consists of a simple verb combined with one or more particles" and whose meaning is typically unpredictable. And Phrasal verbs are two-or three-word idiomatic expressions, consisting of a verb and a particle or a combination of a particle and a preposition (Lewis, 1993; Darwin \& Gray, 1999).

Phrasal verbs have been the source of frustration for learners of English. Many students talk about the difficulties they have using the phrasal verbs. Phrasal verbs are widely used by native speakers of English but they have been found to be difficult for second language learners to master (Moon, 1997; Kao, 2001). The subject of how best to teach phrasal verbs is still quite controversial. Although teaching of phrasal verbs has been daunting and difficult for teachers, and therefore tedious for learners, it is necessary to develop our students' skills in understanding and using them. Since phrasal verbs are frequently used by native speakers both in written and spoken English, students need to be encouraged to learn them. "There is no specified way or a programmed manner in which a student can learn all the phrasal verbs, nouns, adjectives, and idioms. The authors observe that the only way to acquire such knowledge is by extensive reading and listening" (Al-Sibai, 2003).

Avoid teaching phrasal verbs in alphabetical lists. "One big advantage of this method is that it is thorough and comprehensive. But, the problem with a long list is that it is one thing to memorize a phrasal verb and its meaning, but quite another to bring the phrasal verb into your active, everyday speaking and listening" (Dainty, 1992). Through this method "many students know the phrasal verb from a list, but then fail to use it or recognize it in their conversations with native speakers. Lists can be useful, but it may be difficult to transfer this knowledge from the written page to your active knowledge" (Dainty, 1992).

And also avoid teaching phrasal verbs solely on the basis of the verb in them. For example, it would not be advisable to teach every phrasal verb that incorporates the word "get" in one lesson. The phrasal verbs taught this way have nothing else in common other than the verb in them, and it is very difficult to understand and retain the context of whole phrasal verbs in this way (Norman, 2010). How then are we supposed to teach phrasal verbs?

\section{How to Teach Phrasal Verbs?}

Andrzej Cirocki, a proponent of the 'text/ context method', has a useful approach to teach phrasal verbs. He states that if we aim at teaching a few Phrasal Verbs to our students, we should present them in many different real contexts so as to enable them to deduce their exact meaning and to see whether they are transitive or intransitive, separable or inseparable. All these items can be noticed by the students if Phrasal Verbs are presented in authentic contexts (Cirocki, 2003). In his article 'Teaching Phrasal Verbs my Means of Constructing Texts' Cirocki explains his approach in the following way; asking students to read a text entitled 'Hotel Blaze Escape Drama' in which a few Phrasal Verbs can be spotted. 
At present it is not known how the fire started. It seems the fire, broke out in the early hours of the morning. The fire alarm went off at around 2.00 a.m. It is thought it was set off by smoke coming from one of the bedrooms on the first floor. The fire spread quickly from the first floor to the second floor. The fire brigade were called in immediately and fire fighters were on the scene within 15 minutes, but by this time the hotel was already in flames. They fought the blaze and managed to get it under control, though it took them to hours to put the fire out.

Through this method students are able to acquire phrasal verbs better because it is more productive and easier to learn phrasal verbs from a context. "Students are able to pick up the meaning of a phrasal verb from its context even though they have never seen it before" (Dainty, 1992).

While reading 'Hotel Blaze Escape Drama' students get to know new Phrasal Verbs whose meaning and function are explained in the context. Thus, they can be learnt in a natural way. The text constitutes a kind of a background for the new Phrasal Verbs and has been formed to serve as a context, through which new Phrasal Verbs can be presented and explained. However, this is not a genuinely authentic context. Having read such a text, the meaning of these Phrasal Verbs should be clear. If it is not, we should provide students with other contexts so that they could guess the meaning, which makes students remember new Phrasal Verbs much better. Not until then, could they make use of Phrasal Verbs in their own texts (Cirocki, 2003).

Dina Al-Sibai states that in this method Cirocki proposes that students should be encouraged to read a passage where phrasal verbs are presented in real contexts and then deduce their exact meanings as well as determine if they are transitive or intransitive, separable or inseparable, etc. In this way, the context contained in the passage becomes a kind of a background formed to serve as a context through which new phrasal verbs are presented and explained. Employing such a technique, the meanings of various phrasal verbs should become clearer and easier to comprehend. If they are not, students must be offered other contexts so that they can try to fathom the meanings one more time, or even more (Al-Sibai, 2003).

Cirocki maintains that to assure oneself that students understand the meaning of new Phrasal Verbs, teachers can move to the next stage, that is, fixing stage where the establishing of knowledge on Phrasal Verbs takes place. Having deduced meanings of Phrasal Verbs from authentic contexts, it is time to apply such types of exercises so that they could enable students to memorise them much better and also present them in new contexts. These exercises have nothing to do with creativity they are very useful, though. Before students begin constructing their own texts, they first have to work on simple exercises in order to fix new material. Afterwards, they may make use of it in their own texts. For instance, in this exercise students are asked to complete sentences with the appropriate Phrasal Verbs in their correct form (Cirocki, 2003).

catch sb out; fill sth in; cut sth out; take up sth

1. If you want to lose weight, __ potatoes, bread, and sweet things for a week.

2. The oral exam was difficult. The examiner tried to __ (me) by asking some tricky questions.

3. My brother has karate. He trains three times a week.

4. Here are the visa application forms. You have to (them) and return them to the consulate.

In this step establishing the knowledge of phrasal verbs takes place. Teachers are advised to construct fill-in-the-blanks exercises which can enable students to memorize such verbs faster and more accurately. These exercises help to memorize the meanings and utility of newly-acquired phrasal verbs (Al-Sibai, 2003).

In his criticism of the traditional approached to teaching phrasal verbs, Thornbury suggests that "phrasal verbs are best learned on item-by-item basis, and preferably in short contexts that demonstrate their syntactic behaviour" (Thornbury, 2002: 125). According to Thornbury, phrasal verbs should be acquired like the rest of the lexis by providing meaningful context, exposure, and recycling. And Thornbury encourages teachers to provide texts that have high frequency of phrasal verbs in them. Kailani stresses that it is only through genuine practice that accuracy and effectiveness could be increased, regardless of the method or technique being adapted (Kailani, 1995).

According to R. Wyss, if phrasal verbs are presented to students in lists that are void of real or relevant context, students will not be stimulated enough to learn them. He observes that learners need a meaningful contextual background in order to reinforce memory and sustain interest. He suggests that a practical solution for learners would be to deduce the meanings of phrasal verbs as they appear in reading passages (Wyss, 2002).

Another exercise worth recommending is based on providing students with a particular topic and associating it with Phrasal Verbs. For instance; teachers may ask their students to write a letter to their friends talking about their problems with studying. While writing such a letter students have a possibility to make use of Phrasal Verbs of the following type: get down to, keep on with, take down, fall behind, put off, get through, catch up with and many 
others (Cirocki, 2003). In practice Cirocki writes, it may look like this:

Dear Paul,

I have problems with my studies at school I find it difficult to get down to work in the afternoons and I can't concentrate on anything right now. I spend most of my time listening to CDs or watching TV instead of doing my homework. The other students in my class are much better than I am and I find it hard to keep up with them. I can't take down the important things my teacher says because I write very slowly. He has told me that I'm falling behind with my lessons. I'm not good at...

In order to make our students write fully authentic texts, the role of the teacher is confined to proposing an interesting topic. Nevertheless, teachers may also ask their students to make use of as many Phrasal Verbs as possible in their compositions. The main asset of such exercises is the fact that students write about things they are fond of and are really interested in. This enables students to apply long term memory, due to which they will be able to remember certain things for ever and make use of them in various speeches or essays (Cirocki, 2003).

As Nuttall points out "we learnt most of our vocabulary by using it: meeting the spoken words frequently and in situations that we understand, we gradually assimilated their meaning" (Nuttall, 2005).

Shelley Vernon suggests that phrasal verbs need to be learned in the same way as any other type of verb. Students need to learn the phrasal verb as a vocabulary item and also how to use it in sentences. It can help to learn meanings in one lesson and work on integrating the language in a different session. This anyway is helpful with lower levels so students are not overwhelmed. A fun game to use to teach the vocabulary side of phrasal verbs is Call My Bluff Definitions. Here you give each student a phrasal verb to look up in the dictionary and ask everyone to write down the true meaning plus make up two false meanings. It is good to set this for homework so as not to use precious class time. If you want to simplify have students write only two definitions, one true and one false.

At the next lesson, Shelley maintains that, each student reads out the phrasal verb followed by the three definitions. The class stand up and listen all three definitions once. Then on the second reading students sit down if they think a definition is false and stay standing if they think it is true. Let's say the first definition is false and half the students sit down. All those sitting down are still in the game so those standing put their hands on the heads and sit down. They are out for this round. Those still in stand up again and the student reads out definition two. Those who have it wrong are out again and sit down with their hands on their heads. Those that are in continue until all three definitions have been read out. You then let those students award themselves a point. Now everyone is back in again for the next phrasal verb. If playing with adults you can leave out putting hands on heads. That is just a mechanism to prevent cheating, which children are possibly more likely to do than adults! (Shelley, 2007).

Subrahmanian Upendran in his article 'Teaching Phrasal Verbs Using Songs' states that like teaching phrasal verbs many songs can be successfully employed to provide meaningful contexts for learning phrasal verbs. This will be illustrated through the use of the first four lines of the song "Another Day in Paradise" by Phil Collins.

Procedure of this approach:

Students were provided with incomplete lyrics.

The students were given incomplete lyrics of the song "Another Day in Paradise" by Phil Collins and were instructed to familiarize themselves with it by going through it silently. Each line contained a blank, which they would be required to fill in as they listened to the song.

Students were asked to fill in the blanks.

After they had familiarized themselves with the lyrics, the next step involved was to expose the students to the song in small chunks of four lines each. Every segment was replayed several times, till most students were confident that they had written in the appropriate words. It was only when the students completed filling in all the blanks contained in the first stanza that any attempt was made to determine how correct or incorrect their answers were.

Students were asked to volunteer information.

Each of the blanks was taken up one by one and every student in the group was asked what word he/she had used in a particular blank. (Since my focus here is on the teaching of phrasal verbs, I'll confine myself to the first blank in the song, which completes the phrasal verb "calls out".) The different answers provided by the students were put up on the blackboard. No attempt was made to weed out the incorrect answers at this stage. As all answers were being accepted, students enthusiastically revealed what they had put down. Some of the answers given for the first blank was (calls) "out", "on", "off", and "up".

Students were asked the meaning of phrasal verbs. 
When all the students had volunteered information about the word they had inserted in the first blank, they were asked the meaning of each phrasal verb.

What is the meaning of "call out"?

What does "call on" mean?

The meaning of each phrasal verb was discussed individually and when a student provided a definition, which everyone agreed on, it was put up on the blackboard. The participants were asked to use the phrasal verb in a sentence. Examples provided by the students were put up alongside the meaning.

Students were provided with contextual clues.

When the students were unable to define a phrasal verb, there was no attempt to provide them with one. Instead, the phrasal verb was used in a context and all students were expected to guess the meaning. For example, when the students were unable to define "call off", the following context was provided.

"The class is over. You're ready to begin looking through your notes in the short break before the next class. You have a test on that class. Suddenly a student runs into the classroom and shouts that the test is called off as the teacher has left to deal with a family emergency. You are overjoyed, and you throw your books back into your bag and rush to the playground to join the cricket game."

The students were asked to determine the meaning from the context provided. Once the meaning had been arrived at, further examples of how the phrasal verb was used were provided.

John's appointment with the doctor was called off.

The teacher called off the meeting.

Students were asked to study the lyrics again.

When the meanings of all the phrasal verbs had been figured out, the students were then asked to study the lyrics again and determine which phrasal verb was demanded by the context. If, for example, all students agreed on "calls out", they were asked to provide cogent arguments why it couldn't be any of the other phrasal verbs that they had initially come up with. Some of the arguments put forward by the students were: people don't visit someone on the street, they can meet them accidentally, but not 'visit'. The grammar does not permit 'call on'. One can 'call on' someone, but not 'call on to' someone. Getting/providing such answers from/to students ensured that they not only remembered the meaning of the phrasal verb but also where and how it should be used (Upendran 2001).

\section{Conclusion}

Phrasal verbs, one of the most important parts of communication, are frequently avoided by learners of English. One language skill is trying to infer the meaning of a new phrasal verb from the context. "It is safe to say that phrasal verbs, especially those commonly used ones, are very important components in effectively spoken communication, no matter in what kind of language community text it lies. From the angle of language learning for the sake of effective communication phrasal verbs should by no means be avoided" (Chen, 2007). How then are we supposed to emphasize phrasal verbs in English language teaching and learning? "Research has shown that texts and contexts can have a powerful influence on the students' vocabulary growth. Learning words through such technique is along-term process in which meanings are slowly but steadily accumulated. The key here is to focus instructional attention on words that students have encountered in rich texts usually through reading, rather than from word lists that are void of context" (Al-Sibai, 2003). And in this article how to teach phrasal verbs effectively through context is studied.

\section{References}

Chen, Junyu. (2007). On How to Solve the Problem of the Avoidance of Phrasal Verbs in the Chinese Context. International Education Journal, 8(2), 348-353.

Cirocki, A. (2003). Teaching Phrasal Verbs my Means of Constructing Texts. ELT Newsletter. Retrieved $2^{\text {nd }}$ February 2011 from http://www.eltnewsletter.com/column/shtml

Dainty, Peter. (1992). Phrasal Verbs in Context. Macmillan Education.

Darwin, C. M., \& Gray, L. S. (1999). Going after the phrasal verbs: An alternative approach to classification. TESOL Quarterly, 33, 65-83. http://dx.doi.org/10.2307/3588191

Dina. M. Al-Sibai. (2003). Using the Balanced Activity Approach in Teaching Phrasal Verbs to Saudi College Students: A Review of the Literature.

Kailani, T. Z. (1995). A Synthesized Pedagogical Methodology for English Classroom Interactions. International 
Review of Applied Linguistics in Language Teaching. Academic Search Premier Database.

Kao, R. (2001). Where have the prepositions gone? A study of English prepositional verbs and input enhancement in instructed SLA. International Review of Applied Linguistics in Language Teaching, 39, 195-215.

Koprowski, M. (2005). Investigating the Usefulness of Lexical Phrases in Contemporary Coursebooks. ELT Journal, 59(4), 322-332. http://dx.doi.org/10.1093/elt/cci061

Lewis, M. (1993). The lexical Approach. London: Language Teaching Publications.

Moon, R. (1997). Vocabulary connections: Multi-word items in English. In M. McCarthy (Ed.), Vocabulary: Description, acquisition and pedagogy (pp. 40-63). Cambridge: Cambridge University Press.

Norman, Leila. (2010). Teaching Phrasal Verbs to ESL Students. Retrieved $13^{\text {th }}$ January from 2011 http://associatedcontent.com.html

Nuttall, Christine E. (2005). Teaching Reading Skills in a Foreign Language. Oxford: Macmillan Education.

Thornbury, Scott. (2002). How to Teach Vocabulary. Harlow: Longman.

Trask, R. L. (1993). A Dictionary of Grammatical Terms in Linguistics. London: Routhledge.

Upendran, Subrahmanian. (2001). Teaching Phrasal Verbs Using Songs. The Internet TESL Journal, 7(7). Retrieved $15^{\text {th }}$ January from $2011 \mathrm{http} / / /$ iteslj.org/Techniques/Upendran-PhrasalVerbs.html

Vernon, Shelley. (2007). How to Teach Phrasal Verbs to ESL Students. Retrieved 12 ${ }^{\text {th }}$ January from 2011 http://teachingenglishgames.blogspot.com/2007/11/how-to-teach- phrasal-verbs-to-esl.html

Wyss, R. (2002). Teaching English Multi-Word Verbs Is Not a Lost Cause Afterall. ELT Newsletter. Retrieved 5 January from $2011 \mathrm{http}: / / \mathrm{www}$. eltnewsletter.com/back/March2002/art902002.html 